\title{
Factor Affecting In-App Advertisement Purchase Intention: Thailand Case Study
}

\author{
Tosiriwattananon Praewroong and Chanvarasuth Pisit
}

SIIT Thammasat University, Thailand

\begin{abstract}
The growing steadily of the in-app advertisement market that making in-app advertisement is one of major area for advertising product or service from organization. The organization need the consumer to access to in-app advertisement as influence consumer intention to purchase advertise product and service. This study proposes to know how the factors influence consumer intention to purchase advertisement product in-app advertisement in Thai consumer. Based on the Uses and Gratifications Theory (UGT). The study method is a quantitative method that used in this study by applying the Structural Equation Modeling (SEM) technique to the primary data, which is obtained through online questionnaires. The sampling method used was convenience sampling with a total of 400 respondents. The result of this study showed perceived informativeness, irritation, and personalization has significant influence on attitude toward in-app advertisement and intention to purchase advertisement product. Additionally, the finding found that perceived informativeness has positive impact to credibility. On the other hand, perceived entertainment and credibility has insignificant impact on attitude toward in-app advertisement. The study contributes to the literature of marketing in-app advertisement organization, enabling researchers to prioritize the advertising strategy effectiveness from information, irritation, and preference in personalization to help in-app advertisement marketers maximize reach.
\end{abstract}

Keywords: In-app advertisement, purchase intention, UGT, attitude

\section{Introduction}

Social media and mobile application have an influence to the consumers as they are inserted in their usual lifestyle which is making online advertisement receives more attention than traditional advertisement such as television, newspaper, and radio. The mobile application have become a major way which organizations and consumers used to connect for advertising their products. Since, application still developing organizations need to finance the initial application development and the running costs for maintenance of the application. For this reason, advertisement within apps have become the key in generating financing (Rosenkrans \& Myers, 2018).

In 2019, the in-app advertisement of the spending worldwide had grown by $17.6 \%$ to $\$ 333.25$ billion and the next year's spending is believed to continue to grow up, rising to $\$ 517.51$ billion by 2023 (eMarketer, 2019). Since the growing of the in-app advertisement market, in-app advertisement is one of major area for advertising product or service. The organization encourages the consumer to access to in-app advertisement as influence consumer intention to purchase product or service. This means that the intention to 


\section{3rd International Conference on Research in SOCIAL SCIENCES and HUMANITIES}

purchasing represents positive responses to the product (Zhang \& Mao, 2016). If the organization can affirm factors that drive consumer intention to purchasing, they will be able to offer personality recommendation to target consumer group ( Cheung \& To, 2017).

This research aims to identify and examine the main factors that affect mobile users' intention to purchase on in-app advertisements in Thailand by using uses and gratifications (UGT). Further, this research aimed to answer the following question: What are main factors influencing in-app advertisement purchasing intention?

\section{Literature review}

\subsection{In-app advertisement}

In-app advertisement refers to marketing or advertisement messages delivered through applications (Mattke, 2019) and the primary income stream for many of the "free" download app that are provided to user. In-app advertisement is an ad-specific format for applications such as swiping, sensors, global positioning system (Meng et al., 2016) and show in app on the electronic device to marketing or advertising messages by animated, images or video.

\subsection{Intention to purchase}

Intention to purchase indicates that in the future, consumer will plan or be willing to purchase. In the part, most research had showed that an more in intention to purchase reflects an more in the chance of purchasing product or service. If the consumer have a positive intention to purchase, then a positive engagement will promote that purchase.

\subsection{Uses and gratifications Theory (UGT)}

UGT has been developing over the years. Some scholars believe that the UTG was established around the 1960s. In this model, Ducoffe (1996) in the ads value model, they integrated cognitive needs through perceived informativeness (PI) and credibility (CR) constructs and affective needs through perceived entertainment (PE) and irritation (IR) constructs. The literature on mobile advertisement, has indicated that a number of elements contribute to consumer acceptance of mobile advertisement, including the credibility, entertainment, informative, irritation, and attitude the consumer has when being exposed to the message. Attitude (AT) is to be one major factors impact to the advertising context (Cheng et al., 2009). Attitudes toward in-app advertisements affect good or bad interesting and feeling of user in looking for more information.

PI refer to advertisement providing the helpful, useful and productivity information to the consumer, PE factor encourage the consumer in gratifying their esthetic, cheerfulness, avocation or mood release needs, CR are defined by Mackenzie \& Lutz, (1989) that consumer sense the verify of brand, product or service advertised to be honest and confidential in the advertisement, and IR is emotion that your mind has been offended, waying infested messages, or being proposition to others irritant (Bracket \& Carr, 2001). In this paper, model further incorporates personalization (PER) as additional antecedent of attitude. Personalization factor is introduced to be highly relate to mobile advertisement context and able to impact attitude toward consumer adopt in mobile advertising (Sigurdsson, 2018). refers to advertisement are send advertising content or messages to consumer device 


\section{3rd International Conference on Research in SOCIAL SCIENCES and HUMANITIES}

base on our demographic (e.g. age, income, occupation), preference (e.g. product, brands), and interest content $(\mathrm{Xu}, 2006)$. UGT has been applied to investigate attitude toward and adoption in a wide variation of advertisement adoption context such as Web advertising, Facebook and traditional advertising, Online pubic service advertising, and Twitter advertising.

H1: PI has positively effect on attitudes towards in-app advertisements.

$\mathrm{H} 2$ : PE has positively effects on attitudes towards in-app advertisements.

H3: CR has positively effect on attitudes towards in-app advertisements.

H4: IR has negatively effect on attitudes towards in-app advertisements.

H5: PE has positively effect on attitudes towards in-app advertisements.

H6: AT has positively influence on purchase intention.

\section{Methodology}

The target population of the research are mobile users in Thailand because the market of mobile application in Thailand is expanding and spending. Data will be collected online survey by sending an electronic (used Google form to created) by using sample size with an error 5\% and with a confidence coefficient of 95\% in Yamane's formula (Yamane, 1967), the computation from a population of around 400. We were given through a link Google Docs form that directs the questionnaire to them by snowballing technique. Finally, there were 416 respondents. After removal of 16 incomplete respondent, there were 400 completed responses. This study uses quantitative approach using structural equation modeling (SEM).

\section{Result}

\subsection{Validity and Reliability}

The validity of Kaiser-Mayer Olkin (KMO) is exceeds 0.6, Bartlett's Test of is less than 0.05 (Hair et al., 2010). In the reliability of the measures is confirmed the value of Cronbach's alpha is exceeds 0.6. The result as shown in table 2.

Table 2: Validity and Reliability Test

\begin{tabular}{|l|l|l|l|l|l|l|l|l|}
\hline Variable & \multicolumn{1}{|c|}{ KMO } & $\begin{array}{c}\text { Barlett's } \\
\text { Test }\end{array}$ & $\begin{array}{c}\text { Crobach's } \\
\text { Alpha }\end{array}$ & Variable & KMO & $\begin{array}{c}\text { Barlett's } \\
\text { Test }\end{array}$ & $\begin{array}{c}\text { Crobach's } \\
\text { Alpha }\end{array}$ \\
\hline PI & 0.737 & 0.00 & 0.865 & PE & 0.737 & 0.00 & 0.865 \\
\hline PE & 0.719 & 0.00 & 0.843 & AT & 0.704 & 0.00 & 0.809 \\
\hline CR & 0.733 & 0.00 & 0.858 & IPI & 0.711 & 0.00 & 0.824 \\
\hline IR & 0.756 & 0.00 & 0.919 & & & & & \\
\hline
\end{tabular}

\subsection{Confirmatory Factor Analysis (CFA)}

Table 4. Standardized loading factor, construct reliability, and variance extracted.

\begin{tabular}{|l|l|l|l|l|l|l|}
\hline & CR & AVE & & & CR & AVE \\
\hline PI & 0.823 & 0.608 & & PE & 0.811 & 0.589 \\
\hline PE & 0.785 & 0.549 & & AT & 0.852 & 0.659 \\
\hline CR & 0.858 & 0.668 & & IPI & 0.739 & 0.501 \\
\hline IR & 0.830 & 0.553 & & & & \\
\hline
\end{tabular}




\section{3rd International Conference on Research in SOCIAL SCIENCES and HUMANITIES}

May 21-23, 2021

\subsection{Structural equation modeling analysis}

Figure 7: Structural equation modeling analysis the model the intention to purchase product or service in-app advertisement.

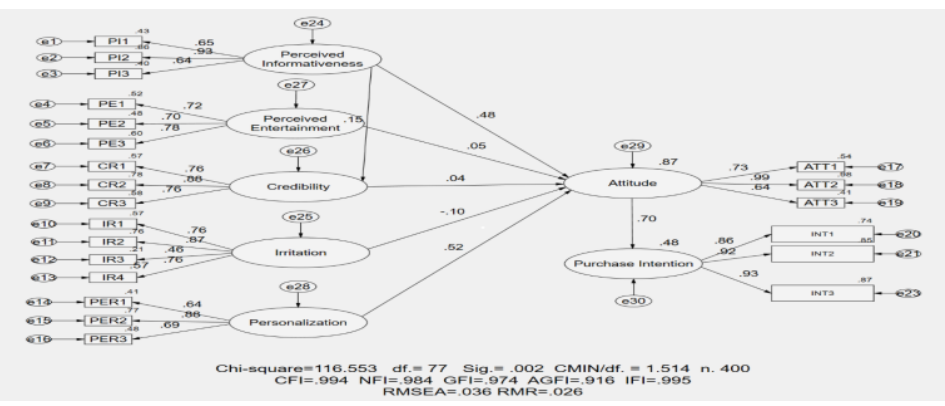

Table 3: Fit Indices for Proposed the model the intention to purchase product or service in-app advertisement.

\begin{tabular}{|c|c|c|c|c|c|c|c|c|c|}
\hline Index & Criteria & Result & References & Result & Index & Criteria & Result & References & Result \\
\hline \multicolumn{10}{|c|}{ Chi - Square $=116.553$ df. $=77.0$} \\
\hline CMIN/df. & $<5.0$ & 1.514 & Bollen (1989) & Good fit & IFI & $\geq 0.90$ & 0.995 & $\begin{array}{l}\text { Hair et al. } \\
\text { (2010) }\end{array}$ & Good fit \\
\hline GFI & $\geq 0.90$ & 0.974 & $\begin{array}{l}\text { Hair et al. } \\
\text { (1998) }\end{array}$ & Good fit & CFI & $\geq 0.90$ & 0.994 & $\begin{array}{l}\text { Hair et al. } \\
\text { (2010) }\end{array}$ & Good fit \\
\hline NFI & $\geq 0.90$ & 0.984 & $\begin{array}{l}\text { Hair et al. } \\
(2010)\end{array}$ & Good fit & RMSEA & $<0.05$ & 0.036 & $\begin{array}{l}\text { Hair et al. } \\
(2010)\end{array}$ & Good fit \\
\hline AGFI & $\geq 0.80$ & 0.916 & $\begin{array}{l}\text { Baumgartner \& } \\
\text { Hombur,(1996) }\end{array}$ & Good fit & RMR & $<0.05$ & 0.026 & $\begin{array}{c}\text { Diamantopoulo } \\
\text { s et al. (2000) }\end{array}$ & Good fit \\
\hline
\end{tabular}

Table 4: Analysis statistics the structural equation modeling analysis the model.

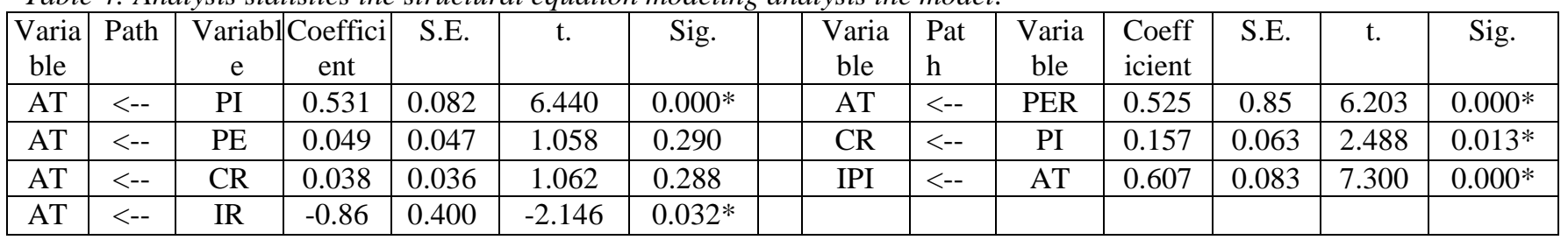

$*$ Sig. $<0.05$

\section{Discussion and Conclusion}

Respondents associate perceived informativeness with timely information and trustworthy sources. To make the organization and product be seen as providing information similar product information, and up-to-date, be directly to the consumers. According to respondents' perceptions, in-app advertisement has a low entertainment level that are not surprising because in-app advertisements displayed on an application have limitations e.g. internet quota. Credibility factor has low impact predictor. This showed that, when respondents find in-app advertisements to be credible and trustworthy, they have less positive impact attitudes to them. Due to imperfection of the market, consumers in this market often deep worry about the honesty of in-app advertising. We have suggested to make credibility of in-app advertising by considering strategies e.g. money-back guarantees. The irritation is strongly felt to be negatively impact consumer attitudes toward in-app advertisement. The caused on unpleasant reaction from the frequency of appearing, sizing of feature and placement of in- 


\section{3rd International Conference on Research in SOCIAL SCIENCES and HUMANITIES}

app advertisement. Additionally, perceived informativeness has positively impact to credibility. Communication in advertisement is sensitive in massage, which may require relevant information in the content that may affect advertising credibility. The study showed that personalization helps consumer accepting in online advertisement. When organization can customize the advertisement to fit an individual's preference, the consumer tend to have more positive attitude. In pervious studies, intention to purchase advertised product in-app advertisement is positively influenced by strong attitude, and strong attitude is from in-app advertisement that presented the appropriate information, less irritation, and customized advertised product fit individual preference. Moreover, the massage fully of inform can help consumer believable in the in-app advertisement. This study indicated consumer positive attitude in-app advertisement tends to have more chance to purchase the product or service in-app advertisement.

The limitation of our study is the data sampling method is utilized. Moreover, the result may be limited by using describe Thai consumer. Therefore, further study may need to explore whether and how differences in other cultural. In addition, it could enhance the model by inputting conducting variables, such as lifestyle, as well as demographics. Another limitation is that the study focused on in-app mobile advertisements as type of application.

\section{Acknowledgment}

This work was fully supported by a research grant from Sirindhorn International Institude of Technology, Thammasat University. In addition, I am grateful to my thesis advisor, Dr. Pisit Chanvarasuth for help and constant encouragement.

\section{References}

Brackett, L. K., \& Carr, B. N. (2001). Cyberspace advertising vs. other media: Consumer vs. mature student attitudes. Journal of advertising research, 41(5), 23-32.

Cheung, M. F., \& To, W. M. (2017). The influence of the propensity to trust on mobile users'attitudes toward in-app advertisements: An extension of the theory of planned behavior. Computers in Human Behavior, 76, 102-111.

eMarketer. (2019). Global Digital Ad Spending 2019. Retrieved from https://www.emarketer.com/content/global-digital-ad-spending-2019.

Hair, J., Black, W., Babin, B. \& Anderson, R. (2010). Multivariate data analysis: A global perspective (7th ed.). New Jersey: Pearson Education.

MacKenzie, S. B., \& Lutz, R. J. (1989). An empirical examination of the structural antecedents of attitude toward the ad in an advertising pretesting context. Journal of marketing, 53(2), 48-65.

Mattke, J. (2019). Advertising-Funded IS: A Literature Review on Factors Influencing Users Clicking Behavior for In-App Ads.

Meng, W., Ding, R., Chung, S. P., Han, S., \& Lee, W. (2016). The Price of Free: Privacy Leakage in Personalized Mobile In-Apps Ads. Paper presented at the NDSS.

Rosenkrans, G., \& Myers, K. (2018). Optimizing Location-Based Mobile Advertising Using Predictive Analytics. Journal of interactive advertising, 18(1), 43-54.

Sigurdsson, V., Menon, R. V., Hallgrímsson, A. G., Larsen, N. M., \& Fagerstrøm, A. (2018). 


\section{3rd International Conference on Research in SOCIAL SCIENCES and HUMANITIES}

Factors affecting attitudes and behavioral intentions toward in-app mobile advertisements. Journal of Promotion Management, 24(5), 694-714.

$\mathrm{Xu}, \mathrm{D}$. J. (2006). The influence of personalization in affecting consumer attitudes mobile advertising in China. Journal of computer information systems, 47(2), 9-19

Yamane, T. (1967). Elementary sampling theory.

Zhang, J., and Mao, E. (2016). From online motivations to ad clicks and to behavioral intentions: An empirical study of consumer response to social media advertising. Psychology \& Marketing, 33(3), 155-164. 